\title{
TAVSHED SOM MAGT OG AFMAGT
}

\author{
HANNE MARLENE DAHL
}

Tavshed er det fraværende, dét, som ikke siges, og som ikke kan siges. Tavshed kan være svær at indfange og kan kun indfanges delvist og i glimt via forskellige strategier. Den er flygtig og undvigende. Derfor er det også ambitiøst at forsøge at afdække tavshed, og der er grænser for, i hvilken forstand vi kan bemægtige os tavsheden. Det skyldes ikke udelukkende, at vi i vores afdækning af den undvigende tavshed paradoksalt nok genererer nye tavsheder. I det senmoderne samfund underlægges vi ifølge den tyske filosof Byung-Chul Han (2012) en systemtvang om transparens, hvilket kunne bidrage til en fornyet interesse for tavsheder, det vil sige at få gjort det skjulte og tavse transparent og synligt. Men her må et forbehold være på sin plads, nemlig som den britiske samfundsforsker John Law skriver: „Når vi søger kundskab om verden, kan ikke alt bringes til synlighed“" (Law 2007:600; min oversættelse). Vi kan ikke få gjort alt synligt, og nogen vil måske mene, at en artikel om tavshed må blive ganske kort. Men det er ingenlunde tilfældet. Der er skrevet en del om tavshed (Carette 2000; Derrida 1978; Foucault 1984a; Haug 1987; Huckin 2002; Ward \& Winstanley 2003; Whitford 1991), men der savnes konkrete analysestrategier til at identificere tavshed i tekster. Derfor vil denne artikel søge at besvare spørgsmålet: Hvordan kan tavshed eller dele heraf identificeres i tekster? Spørgsmålet besvares ikke udtømmende, men ved at beskrive tre tilgange kan tilgroede veje ind til det flygtige gøres synlige.

Der eksisterer forskellige former for tavshed. Vi kan muligvis alle genkende den situation, hvor en person rejser et spørgsmål i en forsamling, og det negligeres. Spørgsmålet besvares aldrig. Her er der én eller flere, som bevidst eller ubevidst tavsliggør en person. ${ }^{1}$ Det er ikke den form for tavshed, som denne artikel kredser om. Det er heller ikke de tavsheder, som er resultatet af, at ét eller flere individer bevidst tilbageholder information (Huckin 2002:348), det vil sige, hvor tavshed er en magtstrategi i et socialt spil. I stedet koncentrerer jeg mig om de 
samfundsmæssige, diskursive processer med et analytisk fokus på tekster. Dermed samles interessen om de tavsheder, der i en overordnet optik begrænser, hvad vi kan tænke og sige. De tavsheder er både forbundet med magt og afmagt. Magt slører nemlig sig selv som magt via tavsliggørelse, samtidig med at tavshed er forbundet med afmagt, det vil sige med dét, som ikke kan siges.

Tavshed er imidlertid er ikke bare „noget“, som er. Tavshed er ikke bare et passivt „negativt rum“ (Ward \& Winstanley 2003:1262-3), men en proces. Den skal produceres og reproduceres af subjekter, det vil sige, at tavsliggørelse er et mere velegnet begreb end tavshed til at indfange, hvad der er på spil, når noget bliver tavst og dermed usynligt.

Men hvorfor er tavshed interessant? Tavshed er interessant, dels fordi den kan give et indblik i samfundets magtmekanismer, og dels fordi selv en partiel afdækning af tavshed kan give et glimt af en anden mulig verden. At det kunne have været anderledes. Hvis noget ikke var blevet gjort tavst, så havde det været italesat og dermed synligt. At afsløre en flig af tavshed kan dermed bidrage til en problematisering af nuværende selvfølgeligheder. Hvorvidt en tavshed er interessant, afhænger af kontekst og erkendelsesmæssig interesse.

I det følgende vil der først være en definitionsmæssig indkredsning af den form for tavsliggørelse, som er i fokus. Derefter vil jeg redegøre for tre forskellige teknikker, der kan anvendes til at identificere tavsheder eller dele af tavsheder: komparativ diskursanalyse, dekonstruktion og erindringsarbejde. Sluttelig konkluderes og reflekteres der over de begrænsninger, en søgen efter tavsheder er underlagt.

\section{Tavshed som en forudsætning for diskursen}

Hvad er tavshed? En måde at forstå tavshed på er at se den som en forudsætning for en diskurs. Det er karakteristisk for poststrukturalismens opfattelse af tavshed (Derrida 1976, 1981; Foucault 1984). Det vil sige, at diskursen forudsætter en andethed, nemlig dét, som er udenfor, og som samtidig er en forudsætning for diskursen. Dermed bliver det udenfor, det, som her kunne kaldes tavshed, en del af det indenfor, hvorved det får en konstitutiv karakter (Staten 1985). Det udenfor bliver en mulighedsbetingelse for det, som er (nemlig en given diskurs $i$ dette tilfælde). Tavsliggørelse er derfor en proces inden $i$ diskursen. Tavshed er en mulighedsbetingelse for diskursen og tillader diskursen at maskere sin egen skabelse (Carette 2000:32-33). Tavshed er det, som forsvinder ud af diskursen, når den tabende position ikke vinder i kampen om at rammesætte - sætte ord på - den sociale og politiske orden. Foucault beskriver forholdet således: 
Tavshed selv - det som man nægter at sige, eller det som er forbudt at nævne $[\ldots]$ - det er i mindre grad diskursens absolutte grænse [...] end et element, der fungerer sideløbende med det, som siges, med dem og i relation til dem inden for de overordnede strategier. Der er ingen binær opdeling mellem, hvad man siger og ikke siger [...] (Foucault 1984:27; min oversættelse).

Tavshed fungerer derfor sideløbende med tale og er dermed dens forudsætning.

Der eksisterer uendeligt mange tavsheder. Ikke alle er lige interessante. Det skyldes blandt andet afgrænsningen til andre diskurser, hvor det, som er tavshed i en diskurs, optræder som italesat i en anden diskurs eller på et andet felt. Samtidig har nogle tavsheder kun interesse set ud fra et individuelt perspektiv. Andre tavsheder kan have en større betydning qua deres indlejring i en samfundsmæssig kontekst, og det er de sidstnævnte, som denne artikel fokuserer på. Mine eksempler på tavsheder af generel samfundsmæssig betydning vil på grund af min faglige baggrund stamme fra det politiske felt. Dette betyder ikke, at deres relevans er begrænset til dette felt, da de tre strategier vil kunne anvendes bredt inden for samfundsvidenskaberne.

Jeg vil blandt andet give eksempler på tavsheder, der genereres inden for det, som jeg vil benævne den politisk-administrative diskurs (Dahl 2000). Denne diskurs udgør den forståelseshorisont, som politikere og bureaukrater ser og forstår bestemte problematikker ud fra. En diskurs angiver nogle grænser for, hvad der kan forstås, og hvad der opfattes som muligt (Dahl 2000:15). En given diskurs sætter rammer for de mulige ,policies“, og dermed begrænses „policy“ $i$ sin fremstilling af et politisk problem. Derved bliver nogle ,... temaer og perspektiver ... tavsliggjort i bestemte problemrepræsentationer" (Bacchi 2009:13; min oversættelse). Nogle aspekter bliver eksempelvis tavsliggjort, når samernes rettigheder i henholdsvis en svensk og en EU-kontekst udelukkende reduceres til et spørgsmål om mindretalsrettigheder (Lawrence 2005). En bestemt diskurs om medborgerskab muliggør kun formulering af samernes rettigheder som mindretal og ikke som et oprindeligt folk. Et andet eksempel på elementer af en tavsliggørelse findes inden for den kvalitetsdiskurs, som er blevet dominerende inden for ældrepolitik i de senere år. Ud fra en neoliberalistisk forståelse af „,bedre og billigere" service er der blevet gennemført flere reformer af ældrepolitikken. Kvalitet har været søgt fremmet ved standardisering og ved borgernes frie valg gennem en markedsliggørelse af ældreomsorgen (Dahl 2011; Højlund 2004). Den enkelte borger kan nu vælge mellem et privat firma eller den kommunale hjemmepleje. Ved gennemlæsningen af politiske dokumenter fra perioden 19952010 kan der iagttages noget interessant vedrørende dem, der skal udføre hjælpen til ældre i eget hjem. „Hjemmehjælper“ som begreb forsvinder ud af diskursen efter 2005. Der kommer et fravær dér, hvor begrebet tidligere optrådte. Samtidig 
kan der identificeres nye begreber som „leverandører“ og „personale“. Med de nye begreber forsvinder "noget" ud af diskursen, nemlig detm som kunne benævnes faglige kompetencer (Dahl 2011). De bliver dermed usynlige, og noget andet kan blive mere synligt, nemlig personlige kompetencer såsom fleksibilitet og imødekommenhed. På denne måde hænger det italesatte og tavsliggørelse sammen, da sidstnævnte bliver en forudsætning for mere tale om individuelle karaktertræk og det mere ,personlige“.

$\mathrm{Nu}$ er tavsliggørelse ikke altid en nem proces at identificere. Ovenfor har jeg bevæget mig ud over de tre teknikker og via en genealogisk læsning identificeret skift og tavshed (Dahl 2000). En genealogi er en historisk orienteret diskursanalyse, hvis analytiske greb er fremmedgørelse i forhold til det, som var og er, og er dermed en nemmere adgang til nogle tavsheder end dem, der udelukkende har et nutidigt materiale at forholde sig til. Genealogien er en analytisk strategi, der søger at identificere de konflikter og kampe, der har været og som er blevet undertrykt, udgrænset og forsvundet. Den identificerer dermed både diskursens udgrænsninger og dens regelbundethed. En genealogi kombinerer en hermeneutisk ,verstehen“ med en sprogfilosofisk strukturalisme forstået som sprogets regelbundethed (Dahl 2000). Da genealogien er beskrevet udtømmende, omend til tider forvirrende, af Michel Foucault (1984b, 1993), og da Carol Bacchi har integreret et spørgsmål om tavshed i sin genealogisk inspirerede „What's the problem represented to be?"-tilgang (2009), vil jeg derfor vende blikket mod andre strategier.

Jeg har udvalgt tre strategier, som illustrerer forskellige måder, hvorpå tavsliggørelse kan afdækkes, nemlig komparativ diskursanalyse, dekonstruktion og erindringsarbejde. Skønt de har forskellig oprindelse, kan de supplere hinanden. Mens dekonstruktion udspringer af en poststrukturalistisk tradition ved den franske filosof Jacques Derrida (1976, 1988), har både den komparative diskursanalyse (Jensson 1986; Kantola 2006) og erindringsarbejde (Haug 1987) rod i forskellige grene af kønsforskningen. Komparativ diskursanalyse er en tilgang, der kan anvendes, når et historisk materiale ikke er tilgængeligt i samme udstrækning, som eksempelvis genealogien kræver. Sammenlignet med den komparative diskursanalyse kræver dekonstruktion mindre materiale, og endelig forudsætter erindringsarbejde intet materiale, da det netop som teknik selv kan generere nyt materiale.

\section{Komparativ diskursanalyse}

Denne tilgang anvendes særligt inden for den politologisk-sociologisk orienterede kønsforskning (Jensson 1986; Kvist \& Petterson 2010; Kantola 2006), men 
den er også blevet taget op uden for kønsforskningen (Howarth 2005). Mens komparativ diskursanalyse anskues som ,en potentielt frugtbar form for empirisk forskning" (Howarth 2005:346; min oversættelse), savnes der ofte refleksion over dens perspektiv, mål og forudsætninger (Howarth 2005). Den amerikanske historiker Jane Jensson var den første, der anvendte denne tilgang, dog uden en interesse for tavsheder som sådan i sin sammenligning af den politiske diskurs i USA og Frankrig om familie- og kønsrelationer (Jensson 1986). Komparativ diskursanalyse er derfor ikke i sig selv nødvendigvis opmærksom på tavsheder. Det er en mulighed, som bevidst skal opdyrkes via teknikken og dens anvendelse.

Komparativ diskursanalyse kan fokusere på forskellige former for tavsheder. I sin bog om feministisk statsteori betoner den finske politolog Johanna Kantola, at „sammenligninger afslører tavsheder“ (2006:38; min oversættelse), men det er ikke tavsliggørelse inden for diskursen, hun har fokus på. Det ses af hendes metodiske refleksioner over valget af empirisk materiale - det finske parlaments debatter - og implikationerne af dette valg:

En mulig ulempe ved denne tilgang er, at den ikke forsyner os med materiale eller rum for tavsliggjorte diskurser, da disse ofte er for marginaliserede til at blive artikuleret i parlamentet. Eksempelvis figurerer de etniske minoriteters stemmer som samer eller romaer ikke, hvorfor deres mulige mistillid til staten ikke ses i de finske debatter (op.cit.45; min oversættelse).

Det fremgår af citatet, at det er de ekskluderede stemmers tavshed, som er hendes bekymring her: de (potentielt) ekskluderede marginaliserede grupper som eksempelvis samerne eller romaerne. Hendes tilgang kan således ikke indfange, hvordan eksempelvis diskursen om medborgerskab ekskluderer bestemte grupper således som i den tidligere nævnte analyse af den svenske diskurs (Lawrence 2005).

Den britisk-sydafrikanske politolog David Howarth (2005) argumenterer for, at en sammenligning af tekster muliggør en fremmedgørelse fra tekstens naturaliserede kontekst gennem konfrontationen med en anden tekst, der gerne ikke er alt for lig den første tekst. På denne måde kan komparativ diskursanalyse anvendes til at identificere tavsheder i diskurser, som opererer ved at opretholde selvfølgeligheder (Rönnblom 20011:21). Når tavsheder fungerer som forudsætning og retfærdiggørende mekanismer for en given status quo inden for diskursen, angiver Howarth to måder, som tavsliggørelse kan afsløres på. En given tekst kan konfronteres med en anden tekst fra en anden periode eller en anden kontekst, eller den kan konfronteres med et ideal som er „udmøntet i ekstrem grad“ (Howarth 2005:333-5; min oversættelse). I det følgende uddybes begge strategier hver for sig. 
I en komparativ analyse sammenligner de svenske politologer Elin Kvist og Elin Petterson politiske diskurser om betalt husligt arbejde i henholdsvis Sverige og Spanien (2010). Det gør de i en nutidig og feministisk optik. Det analyserede materiale er fra den samme periode, men den velfærdsstatslige kontekst er forskellig. Dermed kan det, som italesættes i Spanien, kaste lys på tavsheder i den anden kontekst, nemlig den svenske - og omvendt. Eksempelvis bliver det tydeligt, hvordan etniske og kønsmæssige segregationsmønstre i forhold til betalt, husligt arbejde ikke sættes i tale i en spansk kontekst. Migrantarbejderes vilkår problematiseres ikke i Spanien, hvilket sker i Sverige. Hvilke processer af tavsliggørelse der kan identificeres, afhænger af ens erkendelsesmæssige interesse og af den valgte kontekst til kontrastering. Såfremt et andet land/velfærdsregime havde været valgt, $\mathrm{fx}$ England, kunne andre sprækker i den spanske diskurs været blevet synlige.

I en dansk sammenhæng har den danske skoleforsker Jette Kofoed anvendt midlertidige komparationer, når resultater fra to forskellige forskningsprojekter er blevet sammenlignet (Kofoed 2008). Konteksten er den københavnske folkeskole, ${ }^{2}$ men materialet er genereret på forskellige tidspunkter med 10-15 års forskydning og med parallelle erkendelsesmæssige interesser. Sammenligningen er tematisk centreret om straf og elevmægling, hvor elevmægling er et redskab til håndtering af konflikter i skoler (op.cit.103). Materialet om elevmægling læses først med udgangspunkt i materialet om straf, senere vendes denne proces om, og materialet om straf læses ud fra det nyeste materiale om elevmægling. Det er en forskydningslæsning, hvor materialet søges læst med forskellige slags briller. På den måde relateres materialet til sig selv, og det bliver muligt at se ud over den umiddelbare bevægelse fra én til en anden subjektiverings- og disciplineringsform i skolen og identificere sprækker af noget, der ellers er på vej til at blive usynligt, eksempelvis hvordan eksplicit normativitet bliver tavsliggjort (op.cit.117). Normativiteten er der stadig, men den bliver i Kofoeds optik gjort mere skjult.

I fraværet af en anden tekst, der adskiller sig kontekst- eller tidsmæssigt, er det muligt at anvende en anden slags tekst, nemlig en „ekstrem tekst“, som Howarth nævner. En ekstrem tekst kan enten være en radikalt anderledes videnskabelig eller en fiktiv tekst. Hvis det er en fiktiv tekst, kan det være en novelle eller et digt, der via sin radikalitet bringer nye perspektiver på den eksisterende diskurs. Så ikke alle noveller eller digte kan fungere som en ekstrem tekst; de fungerer kun, hvis de er radikalt anderledes eller ekstrapoleret ud i en yderposition. En nutidig politisk-administrativ tekst om hjemmehjælp kunne eksempelvis sammenlignes med en novelle af den amerikanske forfatter Rebecca Brown „At føle sult“ (Brown 1994), hvorved en afnaturalisering kan finde sted. I den pågældende novelle drager en hjemmehjælper omsorg for en ældre døende kvinde, fru Lindstrøm. Fru 
Lindstrøm har problemer med at synke, og hjemmehjælperen udfolder i novellen et stort praktisk, følelsesmæssigt og kognitivt arbejde med at motivere hende til at spise. Blandt andet bager hun pandekager med ahornsirup til hende, hvorved en særlig familiefortælling om ahornsiruppens symbolske betydning bekræftes. Novellen bidrager dermed til et andet perspektiv på den politisk-administrative tekst, hvorved den selvfølgelighed, som sættes i tale med ord som „visitation“, „leverandører“" og „,funktioner“, bliver afmonteret. På den måde åbner en ekstrem tekst for et nyt tænkeværktøj, ${ }^{3}$ der kan bidrage til dels at studere italesættelse af nye processer i omsorgen og dels til at identificere det fortsat usynliggjorte, nemlig det motiverende og følelsesmæssige arbejde, som udføres.

Komparativ analyse er en strategi under udvikling. Den muliggør forskerens fremmedgørelse i forhold til den givne tekst via sammenligninger med tekster fra andre kontekster og andre tider og via forskydningslæsninger. Men også ikkevidenskabelige tekster (fiktion) kan fremme opdagelsen af tavsheder eller dele heraf og specielt de tavsheder, der er tegn på afmagt og er udelukkede, glemte diskurser.

\section{Dekonstruktion}

Dekonstruktion associeres med Derrida, selvom han er skeptisk over for begrebet (Derrida 1988). Både Foucault og Derrida anså tavshed som noget inden i diskursen, men Derrida var mindre optimistisk end Foucault i forhold til at afdække sådanne praksisser. ${ }^{4}$ Mens dekonstruktion på den ene side er en teknik, der anvendes på en tekst, er den på den anden side også noget, der allerede finder sted i teksten selv. Dekonstruktion er således en intervention i teksten, hvor dens dikotomier og hierarkier identificeres, opløses og rekonstrueres af forskeren (Dahl 2000). Men dekonstruktion er også allerede noget, der finder sted i teksten: „Dekonstruktion finder sted. Det er en hændelse, som ikke afventer intentionalitet, bevidsthed eller subjektets organisering eller moderniteten. Det konstruerer sig selv" (Derrida 1988:4; min oversættelse; original kursiv). Den dynamik skyldes undertrykkelse af det andet i teksten, og denne proces efterlader sig spor i teksten som den kontinuerligt prøver at slette eller viske væk. Ifølge Derrida vil en fuld tilstedeværelse, en fuldt ud konstitueret totalitet, være en umulighed, da en hvilken som helst essens kontinuerligt undergraves indefra (Derrida 1976, 1981; Staten 1985).

Feminister som den australske sociolog Joan Eveline (1994) har anvendt Derrida og den amerikanske litteraturforsker Daphne Patai (1983) til at identificere, hvordan tavshed bidrager til at opretholde maskuline privilegier. Patai argumenterer for, at to strategier er nødvendige for at kønsforskningen skal undgå 
en reproduktion af det bestående kønssystem (op.cit.178-82). En af disse er en ændring af vores relevansregler, så der ikke fokuseres på kvinders position som „det andet" (i forhold til det såkaldte „,mandlige“), men at blikket i stedet vendes mod mænd som det specifikke, idet deres universelle status ophæves. I lighed med Patai omdirigerer Eveline vores blik fra de forurettede (kvinder, kvindelighed og feminint associerede værdier) til det normaliserede og de privilegerede (mænd, maskulinitet og værdier associeret med maskulinitet), det, som Eveline kalder „politics of advantage“, det vil sige „fordelenes politik“. Ligesom Derrida argumenterer hun for, at privilegier og ugunstige forhold er gensidigt relaterede: ,,.. sporet af privilegier findes i relation til det underprivilegerede" (Eveline 1994: 134; min oversættelse). Eveline foreslår, at de tavse (uudsagte) privilegier, der er knyttet til maskulinitet og mandlige værdier, kan afsløres gennem en intervention $i$ en tekst ved strategisk at vende blikket fra de forurettede til de privilegerede. Eveline illustrerer, hvordan „fordelenes politik“ anvendes ved først at citere en oprindelig tekst, dernæst at ændre blikket ved at udskifte „kvinder“ med „mænd“. I den oprindelige tekst står der:

Og kvinder kan meget vel være underprivilegerede på grund af deres relative effektivitet, da de sædvanligvis arbejder inden for områder, hvor der kun er begrænset mulighed for at udvikle snydepraksisser, som de kan give afkald på til fordel for lønforhøjelser (op.cit.149; min oversættelse; original kursiv). ${ }^{5}$

Denne udsættes nu for en forandring via „fordelenes politik“ og ser nu således ud:

Og mand kunne meget vel være begunstiget af deres relative ineffektivitet, da de sædvanligvis arbejder på områder, hvor der er meget rum for at udvikle snydepraksisser som, der kan gives afkald på til fordel for lønforhøjelser (ibid.; min oversættelse). ${ }^{5}$

I den oprindelige tekst er der fokus på forskelsbehandlingen af kvinder, mens den anden tekst vender blikket mod mænds privilegier og deres fastholdelse. Ved at vende relevansreglerne 180 grader forstyrres det sædvanlige billede, og dermed kan der ske en fremmedgørelse af dét, som vi har lært at opfatte som noget ,naturligt“. Der konstrueres en ny tekst, og dermed kan vi få et glimt af den tavshed, som talen om kvinder (og uligeløn) har været baseret på.

Dekonstruktion er en selvreflekterende, kritisk tilgang til vestlig filosofi og tænkning. I Evelines version bliver den et konkret redskab til at identificere den tavshed, som karakteriser privilegiernes holdeplads. Ved en „fordelenes politik" vendes blikket mod de privilegerede og deres manøvreringsrum. De bliver synliggjorte, problematiseret, og derved kan elementer af tavshed som magt blive synlige. 


\section{Erindringsarbejde}

En tredje teknik er erindringsarbejde. Denne specifikke teknik er udviklet inden for kønsforskningen i en kreds af feminister omkring den tyske psykolog og sociolog Frigga Haug (1987) og senere genfortolket af Crawford, Kippax, Onyx og Gaul (1990) og Widerberg (1995). I lighed med basisgrupperne i rødstrømpebevægelsen ${ }^{6}$ er hukommelsesarbejde kollektivt og transformativt. ${ }^{7}$ Haug har beskrevet teknikkens formål som at søge ,det ikke-italesatte, det tavse og det fraværende“ (Haug 1987:65; min oversættelse). I modsætning til de to forudgående teknikker kan denne metode benyttes til at identificere både individuelle og kollektive tavsheder, men mit fokus vil være på dens potentiale $i$ forhold til en adgang til de mere overordnede tavsheder $\mathrm{i}$ diskursen eller $\mathrm{i}$ diskurserne. Teknikken er krævende for både forsker og deltagere, hvilket vil fremgå af det følgende.

Den australske sociolog Patricia D. Farrar (2001) har udskilt tre faser i erindringsarbejde, der samtidig angiver dets konstituerende elementer, nemlig at genkalde sig og nedskrive betydningsfulde hændelser relateret til en fælles tematik, relatering af erindringer til andre minder og potentielt til teori og endelig analysen af de skrevne tekster eller de optagede fortællinger. „At genkalde sig“ er en måde at bryde stilheden på. En sådan proces faciliteres ofte af et fælles tema. Det kan eksempelvis være ,hår“ i relation til forskning om kroppe og seksualisering (Haug 1987) eller ,det nationale flag“ i relation til forskning om nationen og kønsliggørelse (Jansson, Wendt \& Åse 2008). Erindringer søges beskrevet så detaljeret og udtømmende som muligt.

Erindringsarbejde forudsætter $i$ en vis forstand, at grænsen mellem subjektet og objektet for forskningen udviskes, idet de er en og den samme, i hvert fald i den oprindeligt udviklede teknik (Haug 1987:34). Teknikken forudsætter en gruppe, hvis medlemmer har tillid til hinanden, og at de mødes regelmæssigt (Farrar 2001). I gruppen læser de deres nedskrevne minder og fortællinger højt for hinanden, hvorefter de hver især efterfølgende og skiftevis udtrykker deres opfattelser og ideer. I denne proces søges efter ligheder og forskelle i fortællingerne, hvorved koblinger mellem dem kan etableres. Deltagernes forsøg på at afdække den dominerende diskurs inden for et bestemt tema sker blandt andet ved at lede efter modsætninger, klicheer og tavsliggjorte emner (Onyx \& Small 2001; Berg 2008). At lede efter tavsheder eller tavsliggørelse beskrives på følgende måde:

... gruppen beskriver også det, der ikke er skrevet i minderne (men som de ville have forventet var nedskrevet). Tavsheder er af og til veltalende indikatorer på temaer af stor betydning, men som er for smertefulde eller problematiske for forfatteren (Onyx \& Small 2001:777; min oversættelse). 
Deltagerne afdækker deres egne glemte minder, men de forventes også at distancere sig fra deres egne og andres narrativer for at kunne se, hvad der ikke siges. Det forudsætter et højt refleksionsniveau hos deltagerne, hvilket betyder, at ikke alle forløb lykkes. Et eksempel på et ikke vellykket erindringsarbejde er et norsk projekt om hvidhed (Berg 2007), hvor medlemmerne skulle tænke, erindre og skrive om den normaliserede hvidhed. Det kunne de ikke. Tavshed om hvidhed var ikke i tilstrækkelig grad blevet gjort til et problem i gruppen, inden erindringsarbejdet blev påbegyndt. Med andre ord var der ikke slået sprækker i den dominerende diskurs om hvidhed, hvorfor deltagerne ikke kunne forholde sig til den ønskede problematik.

Erindringsarbejdets succes er afhængig af det valgte tema og de valgte begreber og billeder, der skal sætte gang i erindringsprocesserne hos gruppemedlemmerne. Og som allerede nævnt forudsætter sådan en kollektiv proces en høj grad af tillid. Hvis faldgruberne $i$ erindringsarbejde såsom individualisering og psykologisering kan undgås (Jansson, Wendt \& Åse 2008), er det en anvendelig og effektiv strategi til søgen efter tavsliggørelse. Det er en krævende teknik, da den både er tidskrævende og fordrer en høj grad af selvrefleksion blandt deltagerne.

\section{Konklusion}

Ofte fokuseres der på det italesatte, når magt og dominansrelationer underkastes en analyse. Men der er også magt i tavshed, og i denne artikel har der været sat fokus på tavshed som overordnede, sociale diskursive processer og på nogle af dens aspekter. Jeg har set nærmere på magt som usynliggørelse af magtens privilegier og på magt som tæt forbundet med afmagt, det vil sige det udgrænsede, som ikke kan siges, og hvis spor søges visket væk. Der er også tavshed i magt, idet normalisering gør magtens privilegier naturlige. Disse privilegier er dermed vanskelige at problematisere, som det er blevet vist med eksemplerne om hvidhed og maskulinitet. Tavshed er en grundlæggende del af enhver diskurs både som magt og afmagt. Der vil altid være tavsheder af forskellig slags. Tavshed er ikke bare et fravær af tale, et negativt rum, men en proces, nemlig tavsliggørelse.

Der er redegjort for tre analysestrategier, der hver på sin måde kan løfte lidt af sløret for forskellige former af tavsliggørelse. Den komparative diskursanalyse muliggør forskerens fremmedgørelse i forhold til den givne tekst via sammenligninger med tekster fra andre kontekster og andre epoker, herunder fiktive tekster. Denne strategi er specielt anvendelig i forhold til de tavsheder, der er tegn på afmagt, nemlig de udelukkede, glemte diskurser. Dekonstruktion med en kønsoptik, som vi så hos Eveline, er særlig anvendelig i forhold til den måde, som tavshed produceres på gennem normalisering. Ved en „fordelenes politik“vendes 
blikket mod de privilegerede, som bliver synliggjorte og problematiseret, hvorved elementer af tavshed som magt kan blive synlige. Endelig er erindringsarbejdet brugbart til både at generere eget materiale om tavshed og til at give indblik i tavshed som magt og tavshed som afmagt.

\section{Noter}

Tak til min gode ven og kollega Carol Bacchi, der har været en fremragende dialogpartner i arbejdet med tavshed og de processer, hvorigennem tavshed skabes og reproduceres. Hun har kontinuerligt stillet krævende spørgsmål, der ikke altid let lod sig besvare. Mange af ideerne i denne artikel er udviklet i et samarbejde med hende i årene 2009-2012. Også tak til Torben Beck Dyrberg for konstruktiv kommentering af et tidligere udkast samt Mikkel Hvidtfelt Andersen fra RUB for omfattende og grundige litteratursøgninger.

1. Usynliggørelse ville i en anerkendelsesoptik være en miskendelse (Honneth 1997; Fraser 2003).

2. Den københavnske folkeskole er en tilsnigelse. Der er tilsyneladende tale om to forskellige folkeskoler inden for det samme kommunale styringsregime.

3. „Thinking vehicles“ eller tænkeværktøjer er et begreb, som den amerikanske filosof Donna Haraway har introduceret for at beskrive de processer, hvor kategorier problematiseres og den etablerede mening undergraves (Lykke, Markussen og Olesen 2000).

4. Mellem Foucault og Derrida verserede der i en del år en diskussion om muligheden af en tavshedens arkæologi (Foucault 1967; Derrida 1978; Boyne 1990). Den begyndte med Foucaults forord i Madness and Civilization (Foucault 1967:xiii) og drejede sig om vanskelighederne ved at afsløre tavshed og mulighedsbetingelserne for at gøre det.

5. Begrebet „snydepraksisser“ er en oversættelse af det australske begreb „rorts“, der ifølge månedsbrevet „Oxford Australian Word of the Month“ fra juli 2010 betyder ,,a trick, a fraud; a dishonest practice“, hvilket her hentyder til det at bøje reglerne $\mathrm{i}$ en organisation for egen vindings skyld. Månedsbrevet er downloadet fra www.andc.anu.edu.au.

6. I Dahlerup (1998) er basisgruppernes opkomst og centrale ide beskrevet.

7. Den eneste undtagelse er Widerberg, der har udviklet erindringsarbejde til individuelt brug.

Søgeord: tavsliggørelse, diskurs, analysestrategi, komparativ diskursanalyse, dekonstruktion og erindringsarbejde

\section{Litteratur}

Bacchi, Carol

2009 Analysing Policy: What's the Problem Represented to Be? Frenchs Forest: Pearson Education.

Berg, Anne-Jorunn

2008 Silence and Articulation. Whiteness, Racialization and Feminist Memory Work. NORA 16(4):213-27. 
Boyne, Roy

$1990 \quad$ Foucault and Derrida. The Other Side of Reason. London \& New York: Routledge.

Brown, Rebecca

1994 At føle sult. I: R. Brown: Kroppens gaver. Aarhus: Klim

Carrette, Jeremy R.

$2000 \quad$ Foucault and Religion: Spiritual Corporality and Political Spirituality. London \& New York: Routledge.

Crawford, June, Susan Kippax, Jenny Onyx \&Una Gault

1990 Emotion and Gender: Constructing Meaning from Memory. London: Sage.

Dahl, Hanne Marlene

$2000 \quad$ Fra kitler til eget tøj. Diskurser om professionalisme, omsorg og køn. Aarhus: Politica.

2011 Who Can be Against Quality? A New Story about Home-based Care: NPM and Governmentality. In: C. Ceci, K.Björnsdóttir \& M.E. Purkis (eds.): Perspectives on Care at Home for Older People. London: Routledge.

Dahlerup, Drude

1998 Rødstrømperne. København: Gyldendal.2

Derrida, Jacques

1976 Of Grammatology. Baltimore: Johns Hopkins Press.

1978 Writing and Difference. Chicago: The University of Chicago Press.

1981 Disseminations. Chicago: The University of Chicago Press.

1988 Letter to a Japanese Friend. In: D. Wood \& R. Berbasconi (eds.): Derrida and Différance. Evanston: Northern University Press.

Eveline, Joan

1994 The Politics of Advantage. Australian Feminist Studies 19:129-54.

Farrar, Patricia D.

2001 Too Painful to Remember: Memory-work as a Method to Explore Sensitive

Research Topics. http://epress.lib.uts.edu.au/dspace/handle/2100/414 (hentet 25. januar 2012).

Foucault, Michel

1967 Madness and Civilization. A History of Insanity in the Age of Reason. London:

Routledge.

1980 Two Lectures. In: C. Gordon (ed.): Michel Foucault Power/Knowledge: Selected Interviews and Other Writings 1972-1977 by Michel Foucault. New York:

Harvester Wheatsheaf.

1984a [1976] The History of Sexuality: An Introduction. London: Penguin Books.

1984b Nietzsche, Genealogy, History. In: P. Rabinow (ed.): The Foucault Reader. Middlesex: Penguin.

1993 Diskursens ordning. Stockholm: Brutus Östlings Forlag.

Fraser, Nancy

2003 Social Justice in the Age of Identity Politics. In: N. Fraser \& A. Honneth (eds.):

Redistribution or Recognition? A Political-philosophical Exchange. London: Verso.

Han, Byung-Chul

2012 Transparenzgesellschaft. Berlin: Matthes \& Seitz Verlagsgesellschaft. 
Haug, Frigga

1987 Memory Work. In: F. Haug (ed.): Female Sexualization. London: Verso.

Honneth, Axel

1997 Kampf um Anerkennung. Frankfurt: Suhrkamp.

Howarth, David

2005 Applying Discourse Theory: The Method of Articulation. In: D. Howarth \& J. Torfing (eds.): Discourse Theory in European Politics. Identity, Policy and Governance. Basingstoke: Palgrave Macmillan.

Huckin, Thomas

2002 Textual Silence and the Discourse of Homelessness. Discourse \& Society 13(2): 347-72.

Hundleby, Catherine

2009 Silence and the Limitations of Contextual Objectivity. International Feminist Journal of Politics 11(2):254-67.

Jansson, Maria, Maria Wendt \& Åse Cecilia

2008 Memory Work Reconsidered. NORA 16(4):228-40.

Jenson, Jane

1986 Gender and Reproduction: Or, Babies and the State. Studies in Political Economy 20:9-46.

Kantola, Johanna

2006 Feminists Theorize the State. Basingstoke: Palgrave Macmillan.

Kofoed, Jette

2007 Ansvar for egen elevhed. Suspensive komparationer på arbejde. I: J. Kofoed \& D.

Staunæs (red.): Magtballader - 14 fortællinger om magt, modstand og menneskers

tilblivelse. København: Danmarks Pædagogiske Universitetsforlag.

Kvist, Elin \& Elin Petterson

2010 What has Gender Equality got to do with it? An Analysis of Policy Debates Surrounding Domestic Service in the Welfare States of Spain and Sweden. NORA 18(3):185-203.

Law, John

2007

Making a Mess with Method. In: W. Outhwaite \& S.P. Turner (eds.): The

Sage Handbook of Social Science Methodology. New York \& London: Sage Publications.

Lawrence, Rebecca

2005 Sami, Citizenship and Non-recognition in Sweden and the European Union. In: G. Cant, A. Goodall \& J. Inns (eds.): Discourses and Silences: Indigenous Peoples, Risks and Resistance. Christchurch: University of Canterbury, Geography Department.

Lykke, Nina, Randi Markussen \& Finn Olesen

$2000 \quad$ There are Always More Things Going on Than You Thought. Methodologies as Thinking Technologies. Interview with Donna Haraway. Kvinder, Køn \& Forskning 9(4):52-60.

Onyx, Jenny \& Jennis Small

2001 Memory-Work: The Method. Qualitative Inquiry 7(6):773-86 
Patai, Daphne

1983 Beyond Defensiveness; Feminist Research Strategies. Women's Studies International Forum 6(2):177-89.

Rönnblom, Malin

2011 Poststructural Comparative Politics. What to Compare and How. In: A. Bletsas \& C. Beasley (eds.): Strategic Interventions and Exchanges: A Festschrift in Honour of Carol Bacchi. Adelaide: University of Adelaide Press.

Staten, Henry

1985 Wittgenstein and Derrida. Oxford: Basil Blackwell.

Ward, James \& Diana Wistanley

2003 The Silent Presence: Negative Space within Discourses and the Construction of Minority Sexual Identity in the Workplace. Human Relations 56:1255-80.

Whitford, Margaret

1991 Luce Irigaray: Philosophy in the Feminine. London: Routledge. 